\title{
The Notochord of the Newborn Opossum and Its Fate during Postnatal Development
}

\author{
W. J. Krause and J. H. Cutts \\ Department of Anatomy, School of Medicine, University of Missouri-Columbia, Columbia, U. S. A.
}

Received February 26, 1981

Summary. The notochord was examined by light, transmission and scanning electron microscopy, in 25 pouch young opossums (Didelphis virginiana) ranging in age from 6 hr to 25 days post natum. In the newborn opossum, the notochord forms a thin cylinder within developing vertebral centra and presents diamond-shaped expansions in regions of the developing intervertebral discs. The opossum notochord differs from that of other species in that it appears to consist of a heterogeneous population of light and dark cells, and also in the thinness of the notochordal sheath which never attains the degree of development seen in other animals. The sheath is made up of thin cytoplasmic processes which arise both from the light and dark cells. The processes cross a mucopolysaccharide-filled space and then expand to form a thin cytoplasmic sheath that forms the external boundary of the space. The matrix of the cartilage immediately adjacent to the cytoplasmic sheath shows an increased concentration of microfilaments as compared to the cartilage further from the notochord.

During postnatal development the notochordal tissue in the centra of the vertebral bodies decreases, while in the regions of the developing discs, there is a corresponding increase. At the end of the first week, notochordal tissue in the vertebral centra is represented only by a thin cylinder of mucopolysaccharide which contains cell fragments. In subsequent weeks, as ossification of the centra occurs, both the cartilage and notochordal tissue are replaced by bone. Notochordal tissue in the intervertebral regions contributes to the formation of the nucleus pulposus of the intervertebral discs. Despite its short gestation period of only $121 / 2$ days, the basic structure and fate of the notochord in the opossum is similar to that of other mammals.

The notochord represents the most primitive endoskeletal structure of the vertebrates and at some time during their life history, all vertebrates derive their axial support from the notochord. It constitutes the only skeleton in amphioxus and remains the chief skeletal component of agnathans; in forms higher on the phylogenetic scale, the notochord is replaced by the axial skeleton. Although the notochord provides only transient axial support in mammals, it persists in the adult as the nucleus pulposus of the intervertebral discs and in the adult deer mouse (Peromyscus maniculatus rufinus); remnants of the notochord also are found in the apical ligament of the dens (SENSENIG, 1943). The structure of the notochord has been examined in amphioxus (EAKIN and WESTFALL, 1962), chick embryos (Watterson, Fowler and Fowler, 1954; JuRand, 1962; Carlson, 1973), frog tadpoles (BRUNS and Gross, 1970), developing urodeles (W ADDINGTON and 
Perry, 1962) and developing mammals including man (CARlier, 1890; Minot, 1906; Williams, 1908; Sensenig, 1943, 1949; Leeson and Leeson, 1958; Wolfe, Putscher and VICKERY, 1965).

The opossum (Didelphis virginiana) is North America's only marsupial and has a remarkably short gestation period, lasting only $121 / 2$ days. Immediately after birth, the young find their way into the maternal pouch where each attaches to a nipple and continues its development within the pouch. The newborn is exceedingly immature, not only in external appearance (CUTTS, KRAUSE and LEESON, 1978), but also with respect to the development of visceral structures such as the lung (KRAUSE and LEEson, 1973, 1975; Krause, Cutts and Leeson, 1976a), liver (Cutts, Lesson and Krause, 1973; Krause, Cutts and Leeson, 1975; Paone, Cutts and Krause, 1975) and alimentary canal (Krause, Cutts and Leeson, 1976b, c, 1977). As part of a continuing study of the postnatal development of the opossum we present the details of the light and electron microscopic structure of the notochord in the newborn opossum and briefly examine its fate during postnatal development.

\section{MATERIALS AND METHODS}

Twenty-five pouch young opossums (Didelphis virginiana) were used in the study and included animals that were $6 \mathrm{hr}$ old and 5, 8, 15 and 22 days of age at the time of examination. Ages were determined from snout-rump lengths as described previously (Cutrs et al., 1978). The animals were killed by cervical dislocation and immediately the developing vertebral column, primarily of the thoracic region, was fixed for light and for transmission and scanning electron microscopy.

Tissues for light microscopy were fixed in Bouin's solution or in $10 \%$ buffered neutral formalin, processed routinely for paraffin embeding, and sectioned at $5 \mu \mathrm{m}$. The sections were stained with hematoxylin and eosin, van Gieson or periodic acidSchiff (PAS), before and after digestion with saliva.

For transmission electron microscopy, tissue blocks were fixed for $4 \mathrm{hr}$ at $0^{\circ} \mathrm{C}$ in $3.5 \%$ glutaraldehyde buffered to $\mathrm{pH} 7.4$ with $0.1 \mathrm{M}$ phosphate. The tissues were then washed in phosphate buffer, osmicated in $1.0 \% \mathrm{OsO}_{4}$ at $0^{\circ} \mathrm{C}$ for $2 \mathrm{hr}$ and dehydrated in a series of ethyl alcohol solutions. After clearing in propylene oxide, the specimens were embedded in Epon 812. Thin sections were mounted on uncoated grids, stained with uranyl acetate and lead citrate (REYNolDS, 1963) and examined in an RCA-EMU$3 \mathrm{~F}$ electron microscope operated at $50 \mathrm{kV}$. Thick sections $(0.5-1.5 \mu \mathrm{m})$ of the Eponembedded materials were stained with toluidine blue for light microscopy.

Fig. 1. Segmentation of the notochord in the newborn opossum is shown in a section through the developing vertebral column of the thoracic region. The notochord shows diamond-shaped intervertebral expansions $(d)$ in the regions of forming intervertebral discs $(I D)$ and intravertebral constrictions (arrows) within the developing vertebral centra $(C)$. Hematoxylin and eosin. $\times 100$

Fig. 2. At increased magnification, the region of an intravertebral constriction (arrows) shows scattered cells and cell debris within a dense eosinophilic matrix. Surrounding chondrocytes $(C)$ of developing centra show signs of hypertrophy. Newborn opossum (14 mm). Hematoxylin and eosin. $\times 300$

Fig. 3. In regions of the intervertebral expansions, notochordal cells appear loosely arranged and resemble a mesenchymal tissue. Intra- and intercellular vacuoles are present and the cells appear to be united by thin strands of cytoplasm. At the periphery thin cytoplasmic processes (small arrows) extend from notochordal cells and contribute to a limiting notocdordal sheath (large arrows). Newborn opossum $(14 \mathrm{~mm})$. Hematoxylin and eosin. $\times 300$ 


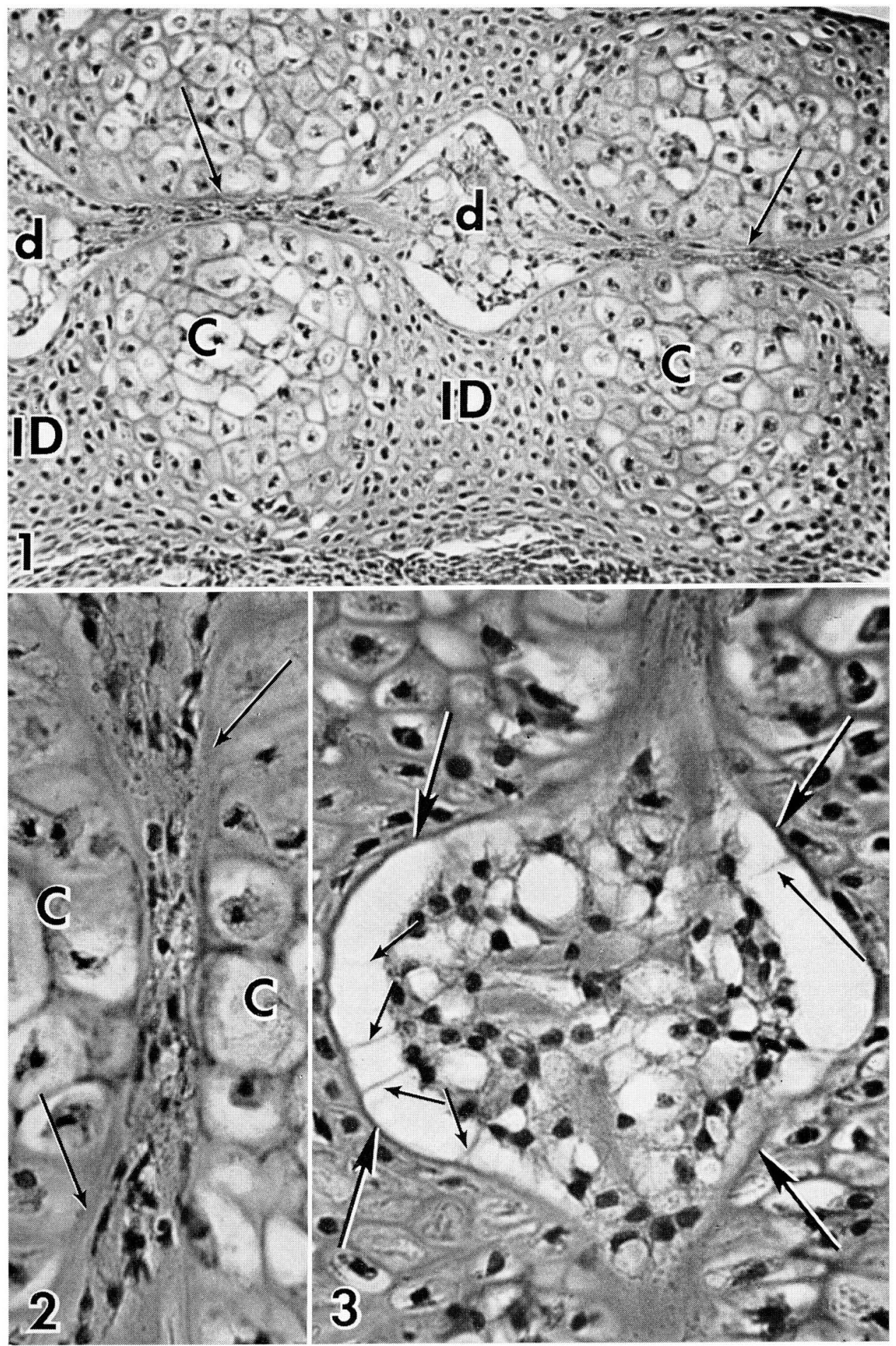

Fig. 1-3. Legends on the opposite page. 
Tissues for scanning electron microscopy were fixed as for transmission electron microscopy. Portions of the vertebral column were cut transversely into $3 \mathrm{~mm}$ blocks, dehydrated in graded ethanol solutions and transferred to amyl acetate prior to critical point drying with liquid $\mathrm{CO}_{2}$. The dried tissues were placed on spinner stubs and coated with gold-palladium alloy to a depth of $20 \mathrm{~nm}$ in a vacuum evaporater. The specimens were viewed in a Cambridge Stereoscan Mark II electron microscope.

\section{RESULTS}

In the newborn ( $6 \mathrm{hr}$ old) opossum, the notochord presents an undulated appearance with diamond-shaped enlargements occupying the central regions of the developing intervertebral discs (Fig. 1,3). The remainder of the notochord is attenuated and appears as a thin cylinder within the cartilagenous blocks of the developing centra of the vertebrae (Fig. 1, 2). In this and the other stages examined, the notochord is avascular.

The notochordal tissue in the intervertebral regions is more cellular than that within the developing centra and numerous vacuoles occur in and/or between the notochordal cells. The material within the vacuoles stains positively with PAS; that in the vacuoles between cells is resistant to digestion with saliva, indicating that the reactive substance is not glycogen, whereas the PAS reactivity in many of the intracellular vacuoles is reduced by prior digestion with saliva. Within the developing centra of the vertebrae, the notochordal tissue contains only scattered cells embedded in a mucopolysaccharide material. In regions nearer the intervertebral discs, the cells are loosely arranged and resemble mesenchymal tissue. In the newborn opossum, the cellular constitutent of the notochordal tissue consists of dark and light cells (Fig. 4).

Thin cytoplasmic processes extend from the cells at the periphery of the notochord and cross a perinotochordal space that, during life, apparently is filled with mucopolysaccharide. The processes appear to form a limiting sheath about the notochord (Fig. 3,5 ). The matrix of the cartilage that immediately surrounds this sheath reacts more intensely with PAS than does that in the remainder of the developing cartilage.

Ultrastructurally, the dark cells often appear attenuated and are characterized by an electron-dense cytoplasm and nucleus. In contrast, the light cells generally are more "epithelial-like" in character, possess abundant, lightly stained cytoplasm and contain euchromatic nuclei (Fig. 6). Both cell types are limited by typical cell membranes, show large accumulations of glycogen, scattered profiles of granular endoplasmic reticulum, occasional lysosomal-like structures and a rare Golgi complex. Mitochondria are small and are observed only infrequently. Intracellular vacuoles are found both in the light and dark cells and may contain glycogen, a light flocculent material or large masses of electron-dense material (Fig. 6). No differences in the structure or concentration of these organelles was observed in the light and dark cells. The intercellular vacuoles are larger and may contain a light flocculent material similar to that in the intracellular vacuoles.

The thin cytoplasmic processes noted by light microscopy are seen to arise from light and dark cells located at the periphery of the notochordal mass. After crossing the perinotochordal space, the processes appear to expand and contribute to a thin cytoplasmic sheath that limits the external boundary of the space (Fig. 6-8). The cartilage matrix that lies immediately adjacent to the cytoplasmic sheath shows a greater concentration of microfilaments than can be seen in regions of the cartilage that lie further from the notochord. 


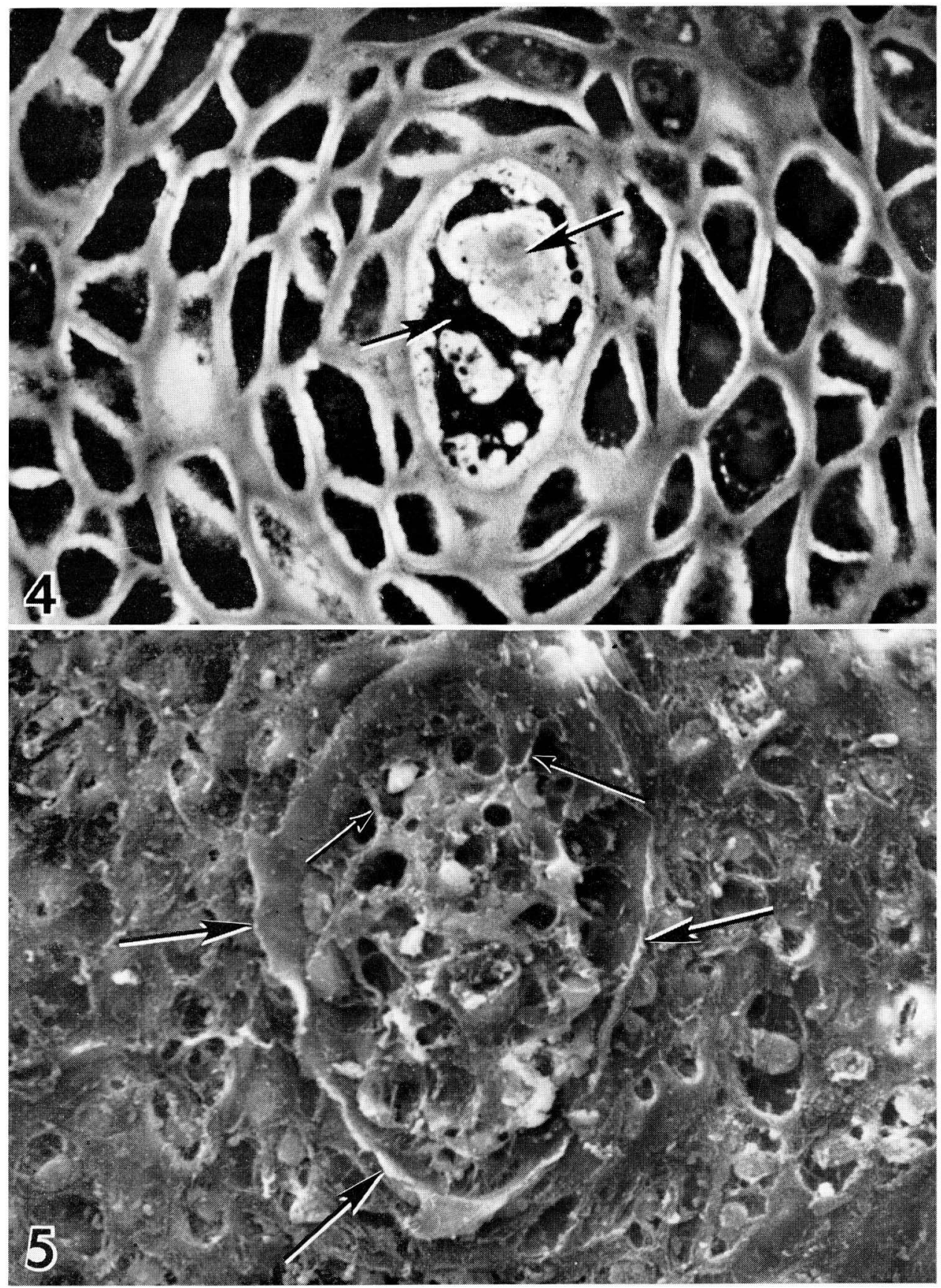

Fig. 4. Cross section of a developing centrum from the thoracic region of a newborn opossum illustrates light and dark cells in the notochord (arrows). Epon 812-toluidine blue. $\times 450$

Fig. 5. Scanning electron micrograph of the limiting notochordal membrane (large arrows) shows thin cytoplasmic processes extending from notochordal cells (small arrows) to contribute to the interior of the membrane. Newborn opossum $(14 \mathrm{~mm}) . \quad \times 550$ 


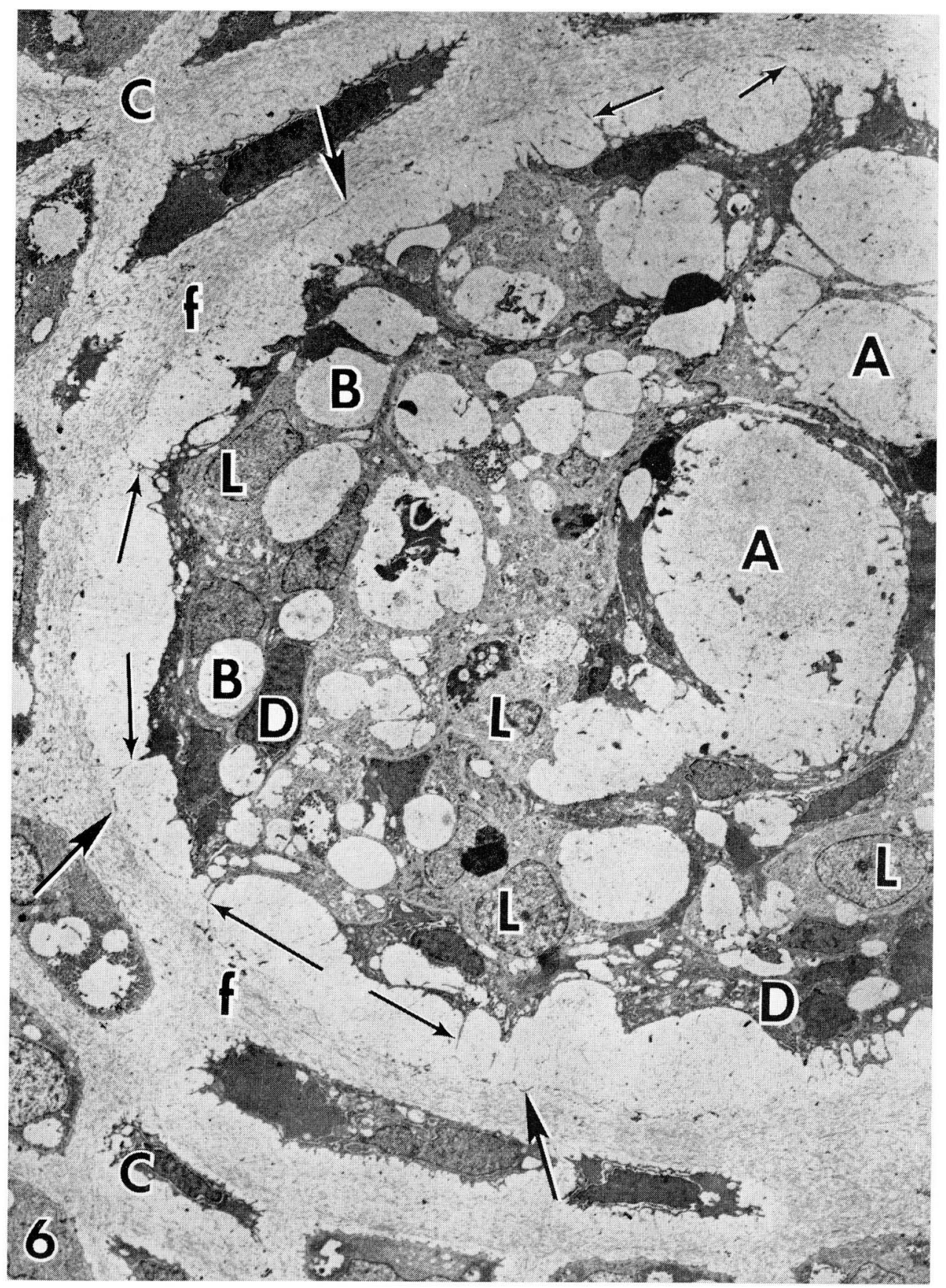

Fig. 6. Cross-section of notochord showing light $(L)$ and dark $(D)$ notochordal cells. Intercellular $(A)$ and intracellular $(B)$ vacuoles are seen. Thin cytoplasmic processes (small arrows) extend from the periphery of the cylindrical mass of notochordal cells, cross a perinotochordal space and contribute to a thin cytoplasmic sheath (large arrows). Immediately surrounding this sheath is a layer of matrix which exhibits a larger condensation of microfibrils $(f)$ than observed in the surrounding cartilage $(C)$. Newborn opossum. $\times 1,200$ 


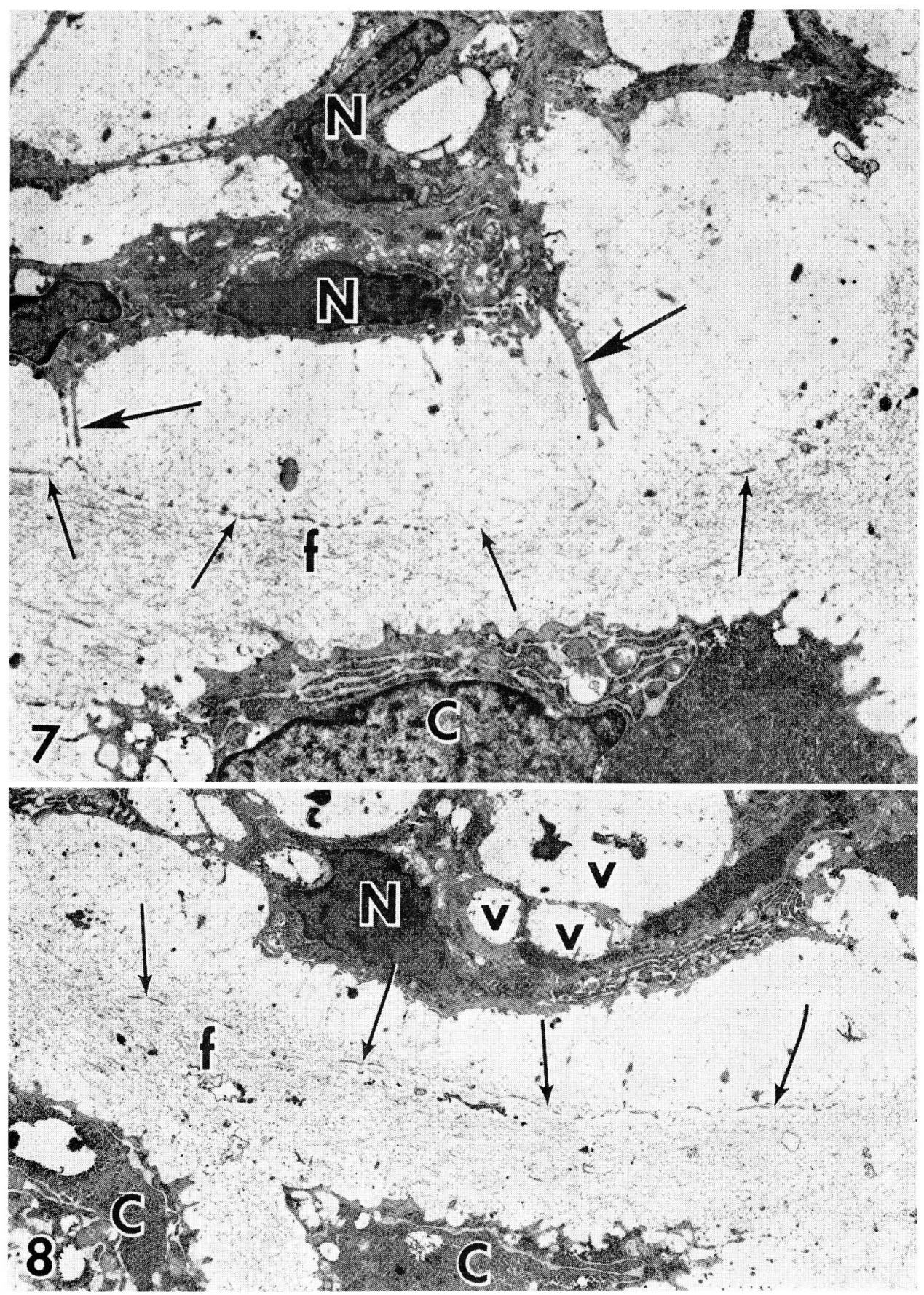

Fig. 7. Notochordal cells $(N)$ at the periphery of the notochord exhibit processes (large arrows) that contribute to the surrounding sheath (small arrows). Microfilaments $(f)$ in the surrounding matrix, and a chondrocyte $(C)$ filled with glycogen, also are shown. Newborn opossum. $\times 5,000$

Fig. 8. A portion of a notochordal cell $(N)$ shows vacuoles $(v)$, profiles of granular endoplasmic reticulum, and a large accumulation of glycogen. The sheath of cytoplasmic processes (arrows), microfilaments $(f)$ of the surrounding matrix and portions of two chondrocytes (C) also are shown. Newborn opossum. $\times 5,000$ 
A loss of notocordal tissue is apparent in the centra of the vertebral bodies of the 8 day old opossum, whereas in regions of developing intervertebral discs, the notochordal tissue appears to show a corresponding increase (Fig. 9). By the end of the second week of postnatal life, the notochord within the centra is represented only by a thin cylinder of mucopolysaccharide in which debris and cell fragments are scattered (Fig. 10). During the third week postnatum, most of the thoracic vertebrae show signs of bone formation with replacement of the cartilage and notochordal tissue by developing bone (Fig. 11). In this and later stages, the notochord in the centra of the vertebrae can be identified only as a cylindrical region of mucopolysaccharide which contains debris (Fig. 12). The notochordal tissue in the intervertebral regions shows increased vacuolation and comes to resemble a mucoid connective tissue. In later stages, it contributes to the formation of the nucleus pulposus of the developing intervertebral discs.

\section{DISCUSSION}

In most mammalian species the structural appearances of the notochord vary with the developmental stage at which it is examined. Cytologically, it is reported to be at first cellular, then to resemble loose mucoid connective tissue before again becoming cellular and resembling cartilage (Williams, 1908; Dawes, 1930). The notochord of the $7.5 \mathrm{~mm}$ opossum embryo appears as a uniform slender rod (Williams, 1908), and Minot (1906) reported that the notochord of the $8 \mathrm{~mm}$ opossum embryo is much larger than that observed in placental animals of equivalent age. Histologically it more closely resembles the notochord of birds and reptiles and consists of a network of cells, separated by large vacuoles that contain a mucoid type of material. WiLliams (1908) noted the presence of a thin amorphous sheath which limited the notochord.

Segmentation of the notochord is evident in the $11.0 \mathrm{~mm}$ opossum embryo, and a larger amount of notochordal tissue is present in regions of the intervertebral thickenings (Minot, 1906; Williams, 1908). As chondrification of the developing vertebrae occurs, the notochordal tissue within the centra decreases in amount, accompanied by a corresponding increase of notochordal tissue in the intervertebral regions. This process continues through the $12 \mathrm{~mm}$ stage at which time the notochordal enlargements assume a diamond-shaped appearance (Williams, 1908). Although the notochordal enlargements change in size during the subsequent stages of development, in the opossum they retain their characteristic diamond shape.

Williams (1908) believed that pressure exerted upon the notochord during chondrification of the vertebral bodies resulted in displacement of notochordal tissue into

Fig. 9. The vertebral bodies of the 8 day old opossum $(2.5 \mathrm{~cm})$ show loss of notochordal tissue from the centra $(C)$ of developing vertebrae with most of the notochord occupying a diamondshaped space in the developing intervertebral discs $(D)$. Hematoxylin and eosin. $\times 100$

Fig. 10. The cellular component of the notochord occupies only intervertebral portions $(L)$ by the end of the second week of postnatal development. That in developing centra is represented by a cylinder of mucopolysaccharide which contains cellular debris (arrows). Hematoxylin and eosin. $\times 250$

Fig. 11. By the third week of postnatal life $(4.5 \mathrm{~cm})$ most vertebral bodies show bone formation with a replacement of the cartilage $(C)$ and notochordal tissue (arrows) in the centrum with bone $(B)$. Hematoxylin and eosin. $\times 150$

Fig. 12. The cylinder of intravertebral notochordal tissue (arrows) in the three week old opossum consists only of a mucopolysaccharide material and cell debris. Hematoxylin and eosin. $\times 250$ 


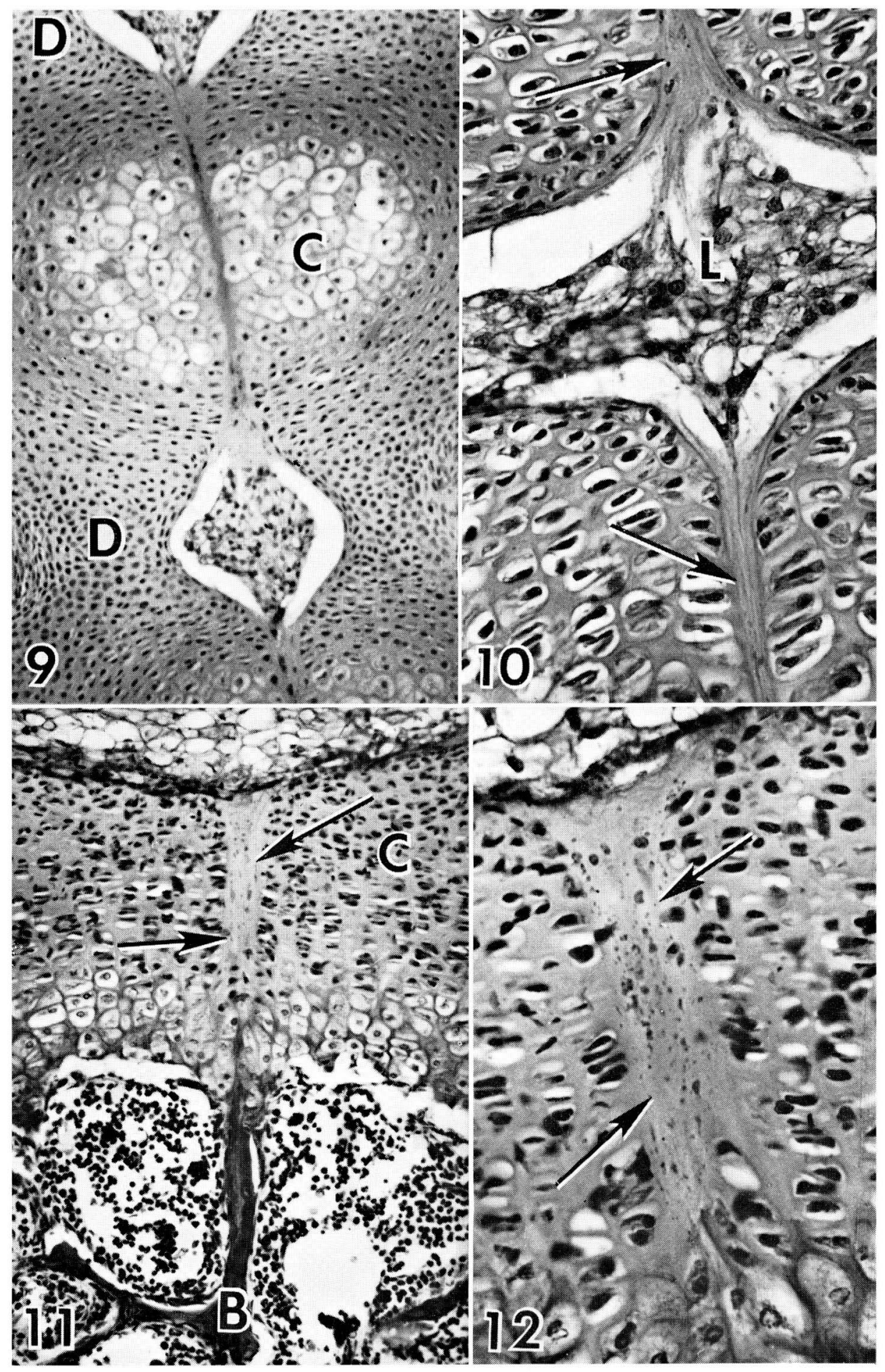

Fig. 9-12. Legends on the opposite page 
the intervertebral regions, and DAwEs (1930) supported this explanation of segmentation of the notochord. Two alternative mechanisms suggested by LEESON and LEESON (1958) considered either a localized proliferation of notochordal cells in the intervertebral regions, or an active migration of notochordal cells from intravertebral to intervertebral regions. Since mitoses were not observed at the time of segmentation in the opossum, the present findings do not support a local proliferation of notochordal cells and the concept of migration or passive displacement of notochordal tissue seems the more attractive. Other factors, such as degeneration of the remaining notochordal cells in the vertebral centra and vacuolization of the notochordal tissue of intervertebral regions also may influence segmentation in the opossum as has been noted in the rabbit (LEESON and LeEson, 1958).

WiLLIAMs (1908) reported the presence of an amorphous sheath which surrounded the notochord of a $7.5 \mathrm{~mm}$ opossum embryo and also noted a thin inner notochordal sheath in a $12 \mathrm{~mm}$ opossum. In the present study, ultrastructural observations revealed two definite zones in the perinotochordal region of the newborn opossum. A layer of mucopolysaccharide within the perinotochordal space is bounded externally by delicate cytoplasmic processes which contribute to a thin limiting sheath. The processes, in turn, are surrounded by microfibrils that lack periodicity and are embedded in a light amorphous material continuous with the matrix of the surrounding cartilage. The matrix immediately surrounding the limiting membrane contains an increased concentration of microfilaments oriented about the circumference of the notochord. The notochordal sheath in the opossum appears to be unique in that it is not as well developed as in other vertebrates (LEEson and LeEson, 1958; Jurand, 1962; W AdDing Ton and Perry, 1962; BRUNs and Gross, 1970).

Another unique feature of the opossum notochord is the presence of light and dark cells, recognizable both by light and electron microscopy. Similar populations of cells have not been reported in other species. Whether the light and dark cells represent two distinct types, or are reflections of different states of physiological activity of a single cell type is unknown. Alternatively, the presence of the two cell types may be the result of fixation artifact. However, careful examination of the dark and light cells reveals no differences in the structure of their organelles and they differ only in the electron density of their cytoplasm and nuclei.

Although the opossum is remarkably immature at birth, the structure and fate of the notochord in this species essentially is similar to that described in other mammals.

Acknowledgements. We would like to express our sincere gratitude to Ms. D. Sherman, Research Associate, for her excellent technical assistance.

\section{REFERENCES}

Bruns, R. R. and J. Gross : Studies on the tadpole tail. I. Structure and organization of the notochord and its covering layers in Rana catesbeiana. Amer. J. Anat. 128: 193-244 (1970).

Carlier, E. W.: The fate of the notochord and development of the intervertebral disc in the sheep, with observations on the structure of the adult disc in these animals. J. Anat. 24: 573-584 (1890).

Carlson, E. C.: Intercellular connective tissue fibrils in the notochordal epithelium of the early chick embryo. Amer. J. Anat. 136: 77-90 (1973).

Cutts, J. H., W. J. Krause and C. R. Leeson : General observations on the growth and development 
of the young pouch opossum, Didelphis virginiana. Biol. Neonate 33: 264-272 (1978).

Cutts, J. H., C. R. Leeson and W. J. Krause: The postnatal development of the liver in a marsupial, Didelphis virginiana. I. Light microscopy. J. Anat. 115: 327-346 (1973).

Dawes, R.: The development of the vertebral column in mammals, as illustrated by it development in Mus musculus. Phil. Trans. B218: 115-170 (1930).

Eakin, R. M. and J. A. Westfall : Fine structure of the notochord of amphioxus. J. Cell Biol. 12: 646-651 (1962).

Jurand, A.: The development of the notochord in chick embryos. J. Embryol. exp. Morphol. 10: 602-621 (1962).

Krause, W. J., J. H. Cutts and C. R. Leeson: The postnatal development of the liver in a marsupial, Didelphis virginiana. II. Electron microscopy. J. Anat. 120: 191-205 (1975).

: Type II pulmonary epithelial cells of the newborn opossum lung. Amer. J. Anat. 146: 181-188 (1976a).

: The postnatal development of the alimentary canal in the opossum. I. Oesophagus. J. Anat. 122: 293-314 (1976b).

- : The postnatal development of the alimentary canal in the opossum. II. Stomach. J. Anat. 122: 449-519 (1976c).

- : The postnatal develoment of the alimentary canal in the opossum. III. Small intestine and colon. J. Anat. 123: 21-45 (1977).

Krause, W. J. and C. R. Leeson : The postnatal development of the respiratory system of the opossum. I. Light and scanning electron microscopy. Amer. J. Anat. 137: 337-356 (1973).

- L : Postnatal development of the respiratory system of the opossum. II. Electron microscopy of the epithelium and pleura. Acta anat. 92: 28-44 (1975).

Leeson, T. S. and C. R. Leeson : Observations on the histochemistry and fine structure of the notochord in rabbit embryos. J. Anat. 92: 278-285 (1958).

Minot, D. S.: The segmental flexures of the notochord. Anat. Rec. 1: 42-50 (1906).

Paone, D. B., J. H. Cutts and W. J. Krause: Megakaryocytopoiesis in the liver of the developing opossum (Didelphis virginiana). J. Anat. 120: 239-252 (1975).

Reynolds, E. S.: The use of lead citrate at high pH as an electron-opaque stain in electron microscopy. J. Cell Biol. 17: 208-212 (1963).

Sensenig, E. C.: The origin of the vertebral column in the deer-mouse, Peromyscus maniculatus rufinus. Anat. Rec. 86: 123-141 (1943).

- : The early development of the human vertebral column. Contr. Embryol. Carneg. Instn. 23 (No. 214) : 23-44 (1949).

Waddington, C. H. and M. M. Perry : The ultrastructure of the developing urodele notochord. Proc. Roy. Soc. (London) 156B: 459-482 (1962).

Watterson, R. L. I. Fowler and B. J. Fowler: The role of the neural tube and notochord in development of the axial skeleton of the chick. Amer. J. Anat. 95: 337-399 (1954).

Williams, L. W.: The later development of the notochord in mammals. Amer. J. Anat. 8: 251284 (1908).

Wolfe, H. J., W. G. J. Putschar and A. C. Vickery : Role of the notochord in human intervertebral disc. I. Foetus and infant. Clin. Orthop. 39: 205-212 (1965).

Dr. W. J. Krause

Department of Anatomy

School of Medicine

University of Missouri-Columbia

Columbia, Missouri 65212

U. S. A. 